\title{
Pengembangan Kawasan Wisata Berbasis Masyarakat di Taman Nasional Sebangau Provinsi Kalimantan Tengah (Studi Kasus di Kelurahan Kereng Bangkirai)
}

\author{
Tresy Wigreny ${ }^{1,}{ }^{*}$, Yunikewaty $^{2}$, Tresia Kristiana $^{2}$ \\ ${ }^{1}$ Alumni Program Studi Magister Sains Manajemen Universitas Palangka Raya \\ 2 Program Studi Magister Sains Manajemen Universitas Palangka Raya \\ *Korespondensi: Tresy Wigreny (E-mail: tresywigreny21@gmail.com)
}

\begin{abstract}
This study aims to determine the strategy for the development of community-based tourism areas in Sebangau National Park, Central Kalimantan Province. Descriptive qualitative analysis derived from the SWOT method was applied as an analytical tool. Data were collected through observation, interviews, questionnaires and documentation. Correspondents consist of the local tourism office, Sebangau National Park office, Sebangau district official, Kereng Bangkirai officials, community leaders, local communities and visitors. The results show that, first, the strategy for the development of Sebangau National Park tourist area includes building infrastructure that supports tourism development, and cooperating with the private sector and the government to invest. Secondly, strategies based on SWOT analysis obtained alternative ST (Strength and Threats) strategies. These are, first, to utilize the strength and to pay attention to threats in increasing visits to the Park. Secondly, considering that the Park has potentials that are still original and beautiful and paying attention to threats. Lastly, to develop other tourist areas that increase competition.
\end{abstract}

\section{Keywords}

Potential, Strategy, Development, Tahura, SWOT

\section{PENDAHULUAN}

Pembangunan pada bidang pariwisata umumnya diarahkan sebagai salah satu sektor andalan pemerintah daerah untuk mendorong pertumbuhan ekonomi, peningkatan pendapatan daerah, memberdayakan perekonomian masyarakat, memperluas lapangan kerja dan kesempatan berusaha. Selain itu bidang pariwisata dapat meningkatkan pengenalan dan pemasaran produk dalam rangka meningkatkan kesejahteraan masyarakat. Pengembangan kawasan wisata harus merupakan pengembangan yang terencana secara menyeluruh sehingga dapat diperoleh manfaat yang optimal bagi masyarakat.

Taman Nasional Sebangau (TNS) berada di antara Sungai Sebangau dan Sungai Katingan. Secara administratif, Taman Nasional Sebangau terletak di Kabupaten Katingan, Kabupaten Pulang Pisau dan Kota Palangka Raya di Provinsi Kalimantan Tengah. Taman nasional ini disahkan oleh Keputusan Menteri Kehutanan Nomor: 423/Menhut-II/2004 tanggal 19 Oktober 2004.
Taman Nasional Sebangau (TNS) mempunyai luas membentang sekitar 568.700 he, mengalami perubahan melalui SK Menteri Kehutanan Nomor: 529/MenhutII/2012 tanggal 25 September 2012 dengan luas menjadi 542.141 hektar. Di Taman Nasional Sebangau terdapat tiga destinasi wisata yang berpotensi untuk dikembangkan, antara lain: 1) Sungai Koran di Kota Palangka Raya, 2) Resort Mangkok di Kabupaten Pulang Pisau, dan 3) Danau Punggualas di Kabupaten Katingan.

Para atlet dayung dahulunya menjadikan Dermaga Kereng Bangkirai ini sebagai tempat untuk berlatih dan merupakan tempat dilaksanakannya kejuaraan nasional dayung di Kalimantan Tengah. Di Dermaga Kereng Bangkirai terdapat tribun yang sudah tua dan usang namun sekarang tribun tersebut telah direnovasi dan ditambah dengan pondok-pondok kecil yang dibuat di sekitar pinggiran Sungai Sebangau. Dengan penambahan pondok-pondok kecil dan renovasi yang dilakukan, sekarang Dermaga Kereng Bangkirai telah menjadi salah satu pusat wisata yang banyak diminati oleh wisatawan lokal maupun wisatawan mancanegara. Banyaknya 
wisatawan yang berkunjung dimanfaatkan oleh warga sekitar untuk membuka warung-warung kecil dan juga menyediakan berbagai wahana wisata yang dapat disewa oleh para wisatawan yang berkunjung. Wahana wisata yang ada di Dermaga Kereng Bangkirai yaitu sepeda bebek air, susur sungai, wisata perjalanan ke batu ampar, dan masih banyak lainnya.

Implementasi kebijakan yang terhambat sedang dihadapi oleh pemerintah Provinsi Kalimantan Tengah khususnya sektor pariwisata dengan pusat perkembangan di wilayah tengah Palangka Raya. Saat ini implementasi kebijakan destinasi dan pemasaran pariwisata belum secara serius dilakukan. Pembangunan destinasi pariwisata belum dilakukan dengan optimal (Borneonews, 2017). Begitu juga dengan persoalan pemasaran, yang menikmati kontribusi justru pemerintah daerah di luar Provinsi Kalimantan Tengah.

Seiring berjalannya waktu implementasi Peraturan Daerah tersebut seyogyanya disambut dengan baik oleh seluruh pemerintah daerah kabupaten/kota di Kalimantan Tengah, namun hal tersebut belum terjadi. Informasi yang berkembang di lapangan menunjukkan belum ada satupun pemerintah daerah kabupaten/kota menyambut kebijakan pemerintah provinsi untuk meningkatkan pembangunan kepariwisataan di masingmasing wilayahnya. Dukungan pemerintah kabupaten/ kota tersebut seharusnya dapat ditunjukkan dengan menyusun dan membentuk peraturan daerah turunan yang mengatur tentang Rencana Induk Pembangunan Kepariwisataan Kabupaten/Kota. Sektor pariwisata sepertinya belum menjadi perhatian dan primadona bagi pemerintah kabupaten/kota. Hal tersebut tentu sangat disayangkan sekali, jika mempertimbangkan potensi wisata yang begitu besar yang dimiliki oleh masingmasing daerah kabupaten/kota di Kalimantan Tengah.

Permasalahan dalam hal pemasaran yang sering terdengar oleh masyarakat adalah bahwa Pemerintah Provinsi Kalimantan Tengah cukup santer mempromosikan destinasi pariwisata Kalimantan Tengah melalui berbagai cara seperti mengadakan Festival Budaya Isen Mulang yang diadakan setiap tahun di bulan Mei, promosi melalui cetak brosur dan pamflet yang disebar pada saat pameran di tingkat nasional, promosi melalui website resmi Kalimantan Tengah, dan lain sebagainya, namun hal tersebut masih belum optimal.

Studi yang dilakukan oleh Tamelan dan Harijono (2019) tentang konsep ekowisata sebagai arternatif pengembangan pariwisata merupakan hal yang sanget penting sebagai peningkatan ekonomi masyarakat dalam menunjang kebutuhan pangan dan pendidikan. Konsep ekowisata yang cocok adalah mempertahankan kearifan lokal gotongroyong untuk menyiapkan pangan lokal, serta kegiatan lainnya untuk meningkatkan minat kunjungan wisatawan. Pengembangan ekowisata berbasis masyarakat yang dilakukan di Desa Hadiwarno, Kecamatan Ngadirojo menunjukkan adanya Penguatan daya tarik wisata yang sudah ada dan prospek pembangunan objek wisata yang baru. Hasil dari kegiatan dilakukan menunjukkan bahwa para pelaku ekowisata sangat terbantukan dan kegiatan telah mencapai sasaran yang diinginkan. Selain itu pelaku ekowisata juga dapat memiliki keterampilan pemasaran terhadap produk-produk ekowisata (Prihanta et al., 2017).

Yudhiantari (2002) menunjukkan bahwa model pariwisata yang dapat dikembangkan di Desa Wongaya, Kecamatan Penebel, Kabupaten Tabanan, Bali adalah model ekowisata dengan menjual alam sebagai objek (atraksi) berbasis masyarakat. Selanjutnya Ilyas (2009) menunjukkan daya dukung yang besar dari objek dan kondisi masyarakat setempat, sedangkan daya dukung infrastruktur dan tata kelola masih rendah. Selain itu, Soebagyo (2012) menegaskan bahwa pariwisata dapat menghasilkan pendapatan yang besar bagi suatu daerah apabila dikelola dengan baik.

Kendala yang dihadapi dalam pengembangan ekowisata ataupun desa wisata diantaranya adalah yang pertama belum adanya program kerja desa wisata. Kedua, karena kondisi lingkungan yang kurang bersih. Ketiga, karena tata ruang yang belum baik. Keempat, kurangnya penyuluhan dan pelatihan pariwisata khususunya desa wisata. Kelima, kurangnya fasilitas dan infrastruktur pariwisata (Sunarjaya et al., 2018). Keterbatasan dana juga menjadi kendala dalam pembangunan infrastruktur kawasan ekowisata (Prastio dan Setiyono, 2019). Penelitian yang dilakukan oleh Rani (2014) juga menunjukkan bahwa pengembangan pariwisata memiliki kendala dari segi infrastruktur dimana hal tersebut masih belum mendukung dalam pengembangan pariwisata.

Pemerintah daerah telah membuat strategi guna pengembangan pariwisata di Taman Nasional Sebangau, Namun strategi ini belum mampu memberi kemajuan yang signifikan dalam mengoptimalkan potensi yang ada dengan belum dilibatkannya masyarakat, sehingga untuk mengoptimalkan potensi yang ada serta meningkatkan kunjungan wisatawan diperlukan suatu strategi lain dalam upaya untuk mengembangkan sektor pariwisata di Taman Nasional Sebangau. Strategi ini diharapkan mampu mengoptimalkan dan menjawab kebutuhan wisatawan serta memberdayakan masyarakat dalam pengembangan sektor pariwisata.

\section{METODOLOGI}

Penelitian ini menggunakan tipe penelitian kualitatif dengan pendekatan Analisis SWOT didasarkan pada logika untuk memaksimalkan kekuatan (strength) dan peluang (opportunities), namun secara bersamaan dapat meminimalkan kelemahan (weakness) dan ancaman (treath). Pendekatan penelitian ini dipilih karena Peneliti ingin memecahkan masalah dengan menggambarkan atau melukiskan keadaan objek penelitian pada saat sekarang berdasarkan fakta-fakta yang ada dan dideskripsikan dalam bentuk kata-kata dan bahasa yang diperoleh dari observasi, wawancara, kuisioner, serta dokumentasi yang berkaitan dengan kondisi internal dan eksternal pengembangan kawasan wisata di Taman Nasional Sebangau Provinsi Kalimantan Tengah. Subjek dan objek penelitian diperoleh dari informan. Informan 
merupakan orang-orang yang terlibat atau mengalami proses pelaksanaan dan perumusan program di lokasi penelitian. Informan yang baik harus memenuhi beberapa kriteria informan, yaitu:

1. Masyarakat yang berdomisili di Kelurahan Kereng Bangkirai, Kota Palangka Raya, Provinsi Kalimantan Tengah

2. Berusia antara $25-60$ tahun dan tidak pikun sehingga mampu memberikan informasi data yang representatif

3. Tidak cacat wicara

4. Bisa diajak komunikasi

5. Bersedia menjadi informan.

Informan dalam penelitian ini sebanyak 40 orang.

\section{HASIL}

Analisis SWOT menghasilkan empat (4) kemungkinan strategi alternatif, yaitu:

1. Strategi SO (Strength and Opportunities), yaitu strategi yang mengoptimalkan kekuatan (strength) untuk memanfaatkan peluang (Opportunities), ialah: (a) Mengelola potensi obyek wisata yang dimiliki (kekuatan dari kawasan wisata di Taman Nasional Sebangau dapat dilihat dari panorama alam yang indah, sejuk dan masih asli, sumber air yang melimpah, kondisi keamanan yang baik, suasana obyek wisata yang memberikan kenyamanan, jarak tempuh kawasan wisata yang dekat dengan kota) dengan otonomi daerah memberi keleluasaan untuk mengembangkan potensi wisata, dan (b) Meningkatkan fasilitas prasarana wisata. Setiap wisatawan yang mengunjungi objek wisata tentu menginginkan lokasi wisata yang menarik untuk dikunjungi. Sarana dan prasarana kepariwisataan sangat berpengaruh terhadap meningkatnya jumlah kunjungan wisatawan ke objek wisata. Jika wisatawan merasa kebutuhannya tercukupi, maka akan menjadi kenangan tersendiri bagi pengujung dan ingin mengunjungi kembali objek wisata tersebut. Oleh karena itu, di sekitar ataupun di kawasan objek wisata perlu dibangun sarana dan prasarana pendukung kegiatan kepariwisataan guna keberlanjutan pariwisata di daerah seperti tempat parkir, toilet, tempat sampah, ruang informasi dan lain-lain.

2. Strategi WO (Weaknesses and Opportunities), yaitu strategi yang meminimalkan kelemahan (weaknesses) untuk memanfaatkan peluang (opportunities), ialah: (a) Meningkatkan promosi potensi yang dimiliki kawasan wisata di Taman Nasional Sebangau, (b) Meningkatkan aksesbilitas dengan memperbaiki jalan yang rusak dan pelebaran jalan sehingga meningkatkan jumlah pengunjung di kawasan wisata di Taman Nasional Sebangau, (c) Melakukan koordinasi dengan pihak swasta dan pemerintahan untuk menanamkan modal. Strategi ini dilakukan untuk mendukung kelanjutan pembangunan agar dapat membantu membangun sarana prasarana, akomodasi, atraksi objek wisata pendamping dan sarana lainnya yang belum tersedia. Untuk itu diperlukan koordinasi guna menarik minat investor atau pihak swasta dan pemerintah. Koordinasi dengan pihak swasta untuk menanamkan modalnya dengan membentuk kerjasama atas dasar kesepakatan dan rasa saling membutuhkan untuk meningkatkan kapabilitas dalam bidang pariwisata, dan (d) mengadakan akomodasi pariwisata. Akomodasi merupakan rumah sementara untuk beristirahat apabila wisatawan lelah selama berada di daerah yang dikunjungi, baik itu hotel, losmen maupun villa dengan kenyamanan dan pelayanan yang baik dan kebersihan sanitasinya. Semua fasilitas harus sesuai dengan kebutuhan wisatawan. Jumlahnya harus diperhitungkan berdasarkan jumlah dan lamanya wisatawan tinggal di tempat objek wisata.

3. Strategi ST (Strength and Threats), yaitu strategi yang menggunakan kekuatan (strength) untuk mengatasi ancaman (threats), ialah (a) Mengoptimalkan potensi alam dan keunikan objek wisata dengan mempertahankan dan pemeliharaan objek wisata secara berkesinambungan untuk menghadapi persaingan antar objek wisata, (b) Kondisi keamanan obyek wisata yang baik membantu obyek wisata dari pengunjung yang kurang sadar dalam menjaga keindahan, dan (c) Pengembangan dan pembangunan objek wisata yang ramah lingkungan dengan melakukan kontrol yang tegas terhadap pelaksanaan unsur-unsur pelaku wisata yang tidak sesuai dengan sikap dan tindakan pelaku wisata yang dapat mengancam kerusakan objek wisata.

4. Strategi WT (Weaknesses and Threats), yaitu strategi yang meminimalkan kelemahan (weaknesses) dan menghindari ancaman (threats), ialah: (a) Peningkatan kualitas tenaga kerja professional dalam pengelolaan dan pemeliharaan objek wisata secara berkesinambungan sehingga mengurangi kerusakan lingkungan, dan (b) Meningkatkan keamanan dalam hal pengawasan dan pemeliharaan fasilitas-fasilitas yang telah ada di lokasi serta keamanan pengunjung.

Berdasarkan perhitungan yang dilakukan melalui analisis SWOT, diperoleh nilai akhir dari kekuatan $(2,696)$ kelemahan $(1,507)$, peluang $(2,144)$, dan ancaman $(2,231)$ Terlihat dari hasil perhitungan tersebut bahwa kawasan wisata Taman Nasional Sebangau memiliki kekuatan yang dominan dibanding kelemahannya dan peluang yang lebih besar dibanding ancamannya dengan nilai sebagai berikut:

- Kekuatan - Kelemahan (faktor internal) = 2,696-1,507 $=1,189$

- Peluang - Ancaman (faktor eksternal) = 2,144 - 2,231 $=-0,087$

Apabila nilai-nilai tersebut dimasukkan dalam Matrix Grand Strategy terlihat posisi pengembangan sektor 
pariwisata di Obyek Wisata Taman Nasional Sebangau berada di posisi Strategi Diversifikasi, yaitu memanfaatkan seoptimal mungkin kekuatan dan memperhatikan ancaman yang dimiliki (Gambar 1).

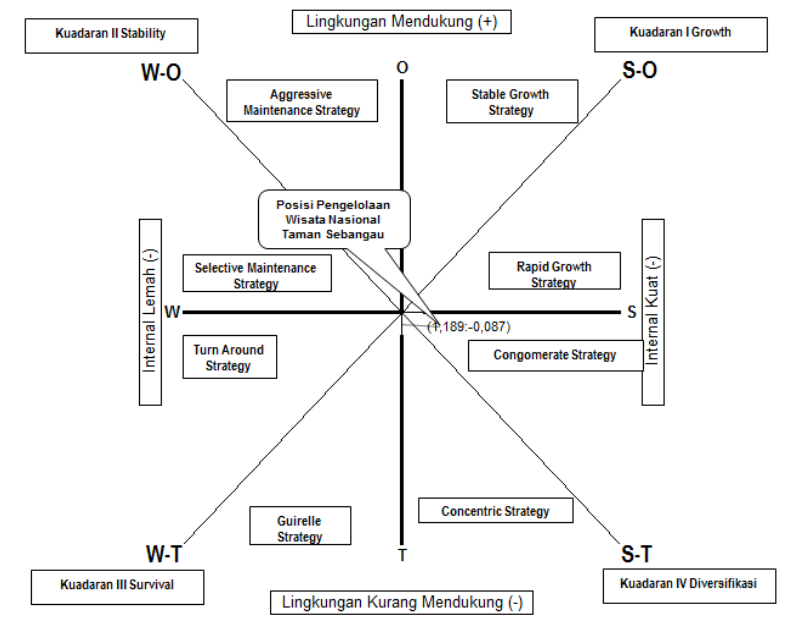

Gambar 1. Matrix Grand Strategy Kawasan Wisata Taman Nasional Sebangau

Berdasarkan gambar pada diagram diatas menunjukkan bahwa titik potong $(1,189 ;-0,087)$ berada pada kuadran IV yaitu strategi diversifikasi konglomerat. Posisi Kuadran IV diversifikasi membuktikan sebuah organisasi yang kuat tapi menghadapi tantangan yang besar atau dengan kata lain organisasi berada pada situasi mantap namun juga menghadapi sejumlah tantangan berat. Meskipun menghadapi berbagai ancaman, perusahaan ini masih memiliki kekuatan dari segi internal. Posisi ini diperkirakan roda organisasi akan mengalami kesulitan untuk terus berputar jika hanya bergantung pada taktik sebelumnya. Oleh karena itu, organisasi disarankan untuk mulai memperbanyak variasi strategi taktisnya. Posisi strategi diversifikasi konglomerat pada Gambar 1 tersebut mengharuskan organisasi berfokus pada sinergi finansial daripada sinergi pada produk, yaitu dengan cara memasukkan investor untuk mendanai diversifikasi yang mempertingkan laba/ keuntungan.

Langkah yang harus dilakukan oleh organisasi pengelola obyek wisata Taman Nasional Sebangau yaitu dengan menambah investor untuk pengembangan obyek wisatanya serta memanfaatkan kekuatan yang dimiliki seperti panorama alam yang indah, sejuk dan masih asli, sumber air yang melimpah, kondisi keamanan yang baik, suasana obyek wisata yang memberikan kenyamanan, jarak tempuh obyek wisata yang dekat dengan kota serta harus memperhatikan ancaman yang bisa saja terjadi yaitu antara lain berkembangnya kawasan wisata lain yang meningkatkan persaingan, kurangnya kesadaran wisatawan untuk menjaga kawasan wisata di Taman Nasional Sebangau, kerusakan lingkungan sekitar kawasan wisata akibat pengembangan yang seenaknya, bencana alam dan meningkatnya peraturan pemerintah (perijinan).

\section{PEMBAHASAN}

\subsection{Faktor Pendorong Pengembangan}

1. Sarana Prasarana

Faktor yang mendukung pengembangan Obyek Wisata Taman Nasional Sebangau Kelurahan Kereng Bangkirai dengan alam yang masih asli dan indah yang didukung dengan suasana pedesaan memberikan udara yang sejuk dan bersih membuat nyaman bagi pengunjung yang didukung dengan keragaman budaya yang unik sehingga mampu sebagai magnet mendatangkan wisatawan; terbukanya jalur penerbangan dalam negeri dari provinsi lain memberi kemudahan aksesibilitas bagi wisatawan untuk berkunjung; pemerintahan yang semakin stabil lebih mampu melaksanakan pembangunan terutama infrastruktur pariwisata; motivasi wisatawan yang berkunjung semakin tersegmentasi sehingga mampu menawarkan keaneka ragaman berbagai produk pariwisata yang ada di Provinsi Kalimantan Tengah; tingkat kreativitas masyarakat dan pengusaha Kalimantan Tengah dalam menciptakan produk-produk yang memiliki keunikan dan berdaya saing tinggi; tingginya minat investor untuk dalam pembangunan dan pengembangan sarana wisata; banyaknya industri/jasa pariwisata untuk memenuhi kebutuhan wisatawan; daya dukung iklim, suasana dan banyaknya obyek daya tarik wisata yang menarik minat wisatawan; dukungan teknologi informasi sebagai sarana informasi wisata Kalimantan Tengah; dan banyaknya event-event pariwisata di Kalimantan Tengah.

Hasil temuan penelitian dilapangan menunjukkan juga bahwa ada beberapa sarana dan prasarana yang diberikan oleh pemerintah Provinsi Kalimantan Tengah melalui Dinas Kebudayaan dan Pariwisata Provinsi Kalimantan Tengah yaitu ruang informasi, tempat parkir, titian, menara pandang, pendopo, bak sampah, bunga, papan/plang nama dari beberapa sarana dan prasarana yang disebutkan berada pada kondisi baik dan bisa digunakan oleh wisatawan dan penduduk sekitar kawasan wisata taman Nasional Sebangau.

Sarana prasarana sangat diperlukan mendukung wisata Taman Nasional Sebangau, hal ini didukung oleh penelitian Fajriah dan Mussadun (2014); Way et al., (2016); Soebiyantoro (2010); bahwa Kawasan wisata yang terkenal dan diminati oleh wisatawan harus memiliki suatu potensi yang dapat dijadikan daya tarik tersendiri untuk memanfaatkan potensi yang ada dapat dilakukan dengan analisis lebih lanjut, salah satunya adalah analisis sarana dan prasarana di kawasan wisata.

\section{Promosi}

Hasil temuan dilapangan menunjukkan Dinas Pariwisata Provinsi Kalimantan Tengah melakukan promosi melalui media massa, media sosial, pamflet dan GNP. Kajian empiris menunjukkan bahwa kesulitan yang dihadapi oleh Dinas Pariwisata Provinsi Kalimantan Tengah dalam mempromosikan dan memasarkan agar 
lebih dikenal oleh masyarakat adalah sebenarnya tidak ada kesulitan karena Dinas Pariwisata Provinsi Kalimantan Tengah sudah secara maksimal mempromosikan wisata Taman Nasional Sebangau.

Penelitian ini didukung oleh penelitian Rahmawati (2014) bahwa aktivitas promosi yang dilakukan dalam menarik wisatawan menggunakan elemen- elemen promosi seperti advertising, personal selling, sales promotion, public relation-publicity. Banyak promosi yang dilakukan negara-negara, tempat wisata, travel, dan lainlain untuk menarik minat wisatawan. Berbagai promosi yang dilakukan seperti iklan, diskon, pameran, website, event-event dan lain-lain. Kunci utama kedatangan wisatawan/pengunjung atau suksesnya program pariwisata sangat bergantung pada aktivitas dan strategi promosi yang dilakukan.

\section{Program Pengembangan Wisata Taman Sebangau}

Dinas Pariwisata Provinsi Kalimantan Tengah akan terus meningkatkan destinasi-destinasi lainnya agar dapat meningkatkan kunjungan wisatawan yang pastinya dapat menambah PAD Kalimantan Tengah. Pengembangan objek wisata tentunya melibatkan semua elemen masyarakat. Sesuai dengan tugas dan kewenangannya, pemerintah merupakan pihak fasilitator yang memiliki peran dan fungsi nya dalam pembuatan dan penentu seluruh kebijakan terkait pengembangan obyek dan daya tarik wisata.

Satria (2009), Tondobala (2012), Dewi (2013), Purnamasari (2011), Putri dan Manaf (2013) mengemukakan bahwa daya tarik dalam obyek wisata merupakan salah satu modal utama yang harus dimiliki dalam upaya peningkatan dan pengembangan Obyek dan Daya Tarik Wisata. Keberadaan obyek dan daya tarik wisata merupakan mata rantai terpenting dalam suatu kegiatan wisata, hal ini disebabkan karena faktor utama yang membuat pengunjung atau wisatawan untuk mengunjungi daerah tujuan wisata adalah potensi dan daya tarik yang dimiliki obyek wisata tersebut

Hasil wawancara dilapangan oleh Dinas Pariwisata Provinsi Kalimantan Tengah bahwa program jangka pendek dan jangka panjang yang diterapkan Dinas Pariwisata Provinsi Kalimantan Tengah terhadap kawasan wisata di Taman Nasional Sebangau Provinsi Kalimantan Tengah yaitu Program Pengembangan Pemasaran Pariwisata, Program Pengembangan Destinasi Pariwisata, Program Pengembangan Kemitraan Pariwisata. Pemasaran pariwisata yang baik dapat mendorong peningkatan lapangan kerja yang memadai, karena di dalamnya terdapat kegiatan ekonomi produktif mulai dari kerajinan, kesenian, makanan, transportasi, travel, herbal, dan sebagainya. Pengembangan pariwisata perlu diarahkan pada terciptanya kesempatan kerja dan berusaha di daerah sekitar obyek wisata. Oleh karena itu, penataan dan pemeliharaan obyek-obyek wisata perlu ditingkatkan baik dari segi kualitas maupun kuantitas.
Selain itu untuk mempermudah pergerakan wisatawan menuju destinasi pariwisata dilakukan peningkatan aksesibilitas berupa prasarana transportasi, sarana transportasi, dan sistem tranportasi. Pada pengembangan amenitas destinasi pariwisata, fokus ditujukan pada pembangunan prasarana umum, penyediaan fasilitas umum, dan pembangunan fasilitas pariwisata. Bukan hanya fasilitas dan aksesibilitas, pengembangan masyarakat juga dianggap penting dalam streategi pengembangan destinasi pariwisata. Pengembangan masyarakat tersebut meliputi, peningkatan kapasitas sumber daya masyarakat dan peningkatan kesadaran dan peran masyarakat.

\subsection{Faktor Penghambat Pengembangan}

Adapun faktor-faktor penghambat pengembangan kawasan wisata Taman Nasional Sebangau Kelurahan Kereng Bangkirai dapat dilihat pengembangan yang dilakukan pada kawasan wisata Taman Nasional Sebangau pada umumnya masih sangat sederhana karena obyek wisata ini masih merupakan kepemilikan pribadi. Menurut hasil wawancara yang dilakukan dengan Kepala Dinas Pariwisata, bahwa promosi pariwisata wisata Taman Nasional Sebangau masih tergolong kurang efektif yang terlihat dari belum adanya peningkatan arus kunjungan wisatawan. Hasil wawancara dengan informan mengemukakan bahwa Belum optimalnya pemasaran pariwisata Kalimantan Tengah terutama untuk wisatawan mancanegara. Selain itu belum tertatanya sentra atau zona aktivitas dan fasilitas (belanja dan jajanan/makanan khas); belum optimalnya sarana informasi dan interpretasi terhadap atraksi-atraksi wisata (alam, heritage, buatan manusia); belum optimalnya pengelolaan potensi produk wisata Kalimantan Tengah; minimnya sarana dan prasarana MICE berskala besar; belum optimalnya dukungan sapta pesona pariwisata di Provinsi Kalimantan Tengah; belum optimalnya pemasaran pariwisata Kalimantan Tengah terutama untuk wisatawan mancanegara; belum maksimalnya lama tinggal wisatawan di Kalimantan Tengah; dan dan belum optimalnya integrasi dan koordinasi promosi wisata se Kalimantan Tengah.

\section{IMPLIKASI PENELITIAN}

Pengembangan kawasan wisata di Taman Nasional Sebangau tidak hanya bertujuan untuk mengembangkan wisata tersebut sebagai daya tarik saja, akan tetapi diharapkan dapat memberikan dapat berpengaruh terhadap keputusan pengembangan kawasan wisata di Taman Nasional Sebangau. Telah diuraikannya indikatorindikator dari setiap parameter yang memiliki peranan penting dalam pariwisata namun masih kurang daya dukungnya diharapkan dapat menjadi pertimbangan bagi Pemerintah Provinsi Kalimantan Tengah sebagai instansi pemilik wisata untuk meningkatkan dan membenahi setiap 
indikator yang dianggap kurang memenuhi standar pariwisata, dan memanfaatkan secara optimal indikator yang memiliki daya dukung tinggi sebagai suatu potensi untuk kemudian dikembangkan dengan inovasi-inovasi baru sebagai daya tarik wisata.

Dengan adanya keterlibatan masyarakat sebagai sumber daya manusia yang diperlukan dalam suatu kegiatan pariwisata, diharapkan dapat memacu untuk terus meningkatkan motivasi dari setiap lapisan masyarakat untuk ikut berpartisipasi dan menjadi masyarakat yang sadar wisata. Sehingga dengan adanya keterlibatan dan kerja sama antara masyarakat dengan pemerintah dalam kegiatan wisata di kawasan wisata Taman Nasional Sebangau maka akan meningkatkan kesejahteraan bagi masyarakat setempat.

\section{KETERBATASAN PENELITIAN}

Penelitian ini terbatas hanya pada strategi pengembangan kawasan wisata Taman Nasional Sebangau di Kelurahan Kereng Bangkirai. Penelitian yang akan datang dapat meneliti lebih luas di semua wilayah area wisata Taman Nasional Sebangau, sehingga hasil temuan penelitian dapat digeneralisasi.

\section{KESIMPULAN DAN SARAN}

Berdasarkan hasil penelitian terkait strategi pengembangan kawasan wisata berbasis masyarakat di Taman Nasional Sebangau Kelurahan Kereng Bangkirai sebagai daya tarik wisata, maka disimpulkan:

1. Strategi pengembangan kawasan wisata di Taman Nasional Sebangau antara lain membangun sarana prasarana yang mendukung pengembangan wisata, dan bekerjasama dengan pihak swasta dan pemerintah untuk menanamkan modal. Jika kekuatan dan peluang ditingkatkan serta meminimalkan kelemahan dan menghindari ancaman dilakukan oleh pengelola dan didukung oleh penerapan strategi pengembangan yang tepat, maka kawasan wisata di Taman Nasional Sebangau dapat menjadi wisata unggulan di Palangka Raya.

2. Temuan penelitian menurut analisis SWOT diperoleh alternatif strategi SO (Strength and Opportunities), yaitu strategi yang mengoptimalkan kekuatan (strength) untuk memanfaatkan peluang (opportunities) dengan pertimbangan bahwa kawasan wisata di Taman Nasional Sebangau memiliki potensi masih asli dan indah dan memiliki peluang besar untuk dikembangkan akan tetapi belum termanfaatkan secara optimal. Dari strategi ST terkait strategi pengembangan wisata Taman Nasional Sebangau sebagai daya tarik wisata menghadapi berbagai ancaman, namun masih memiliki kekuatan dari segi internal. Posisi ini diperkirakan roda organisasi akan mengalami kesulitan untuk terus berputar jika hanya bergantung pada taktik sebelumnya. Oleh karena itu, disarankan untuk mulai memperbanyak variasi strategi taktisnya melalui peningkatan kerjasama antara pihak pengelola wisata, lembaga penanggung jawab wisata dan lembaga desa atau pemerintah daerah, melakukan koordinasi dengan pihak swasta dan pemerintahan untuk menanamkan modal.

Berdasarkan pembahasan dan kesimpulan yang dipaparkan, selanjutnya peneliti disampaikan rekomendasi yang diharapkan dapat menjadi masukan bagi pihak-pihak yang terkait dalam strategi pengembangan kawasan wisata berbasis masyarakat di Taman Nasional Sebangau Kelurahan Kereng Bangkirai sebagai berikut:

1. Dalam menjaga potensi kondisi fisik di kawasan wisata Taman Nasional Sebangau Kelurahan Kereng Bangkirai perlu adanya upaya strategi pengembangan dari sumber daya manusia sebagai pelaku kegiatan wisata yaitu wisatawan, masyarakat, pengelola serta pemerintah untuk terus menjaga dan memelihara kelestarian lingkungan agar tetap memberikan feedback yang baik terhadap keberlangsungan hidup khususnya kegiatan pariwisata alam.

2. Untuk mewujudkan strategi diversifikasi yang telah dihasilkan dari penelitian ini perlu adanya pengembangan pariwisata dengan memberikan kesempatan atau mendorong pelaku pariwisata untuk meningkatkan kualitas layanan fasilitas air seperti getek, perahu hias, dan bebek air serta produk makanan dan kerajinan-kerajinan dengan menampilkan potensi lokal. Selain itu dibuat permainan air seperti banana boat, jet ski, dan sebagainya. Pembangunan rumah adat lokal dayak yang berjejer dipinggir sungai TNS yang menampilkan khas dayak dan pertunjukan kesenian di Taman Nasional Sebangau Kelurahan Kereng Bangkirai.

3. Diversifikasi yang signifikan bagi Pihak swasta dan investor diharapkan mampu bekerjasama dengan pemerintah daerah dan masyarakat lokal dalam pengembangan fasilitas pariwisata di Taman Nasional Sebangau Kelurahan Kereng Bangkirai. Hal tersebut selain memberikan keuntungan secara ekonomi dan sosial perusahaan dan masyarakat juga membantu pemenuhan kebutuhan wisatawan. Namun perlu diperhatikan masalah ketertiban dan berwawasan lingkungan.

4. Pemerintah diharapkan lebih memberikan perhatian lebih kepada masyarakat dalam hal pengenalan Taman Nasional Sebangau Kelurahan Kereng Bangkirai secara intensif. Hal ini akan mendorong masyarakat berkembang menjadi insan pariwisata yang etnik. Permasalahan batasan kebijakan atau hukum yang membatasi pengembangan sarana dan prasarana pariwisata perlu ditindaklanjuti guna mengoptimalkan aspek amenitis pariwisata. Izin atas pembentukan dan mempertegas organisasi perlu 
dilakukan agar organisasi pariwisata berjalan sesuai harapan.

5. Masyarakat lokal diharapkan dapat berpastisipasi secara nyata dalam pengelolaan kegiatan wisata di Taman Nasional Sebangau Kelurahan Kereng Bangkirai. Jangan acuh tak acuh akan potensi yang dimiliki. Tunjukan sikap yang baik bagi para wisatawan supaya memberikan kesan yang baik.

6. Prioritas objek wisata Taman Nasional Sebangau Kelurahan Kereng Bangkirai seharusnya dikembangkan lebih optimal lagi baik oleh pengelola kawasan wisata, dinas terkait, Pemerintah maupun masyarakat, dengan melengkapi fasilitas untuk wisatawan yang masih kurang misalnya perluasan lahan tempat parkir, taman untuk beristirahat, sekretariat diperluas dan diperbaiki untuk ruang tunggu wisatawan masuk serta adanya penginapan-penginapan bagi wisatawan.

7. Intensitas sosialisasi dan pelatihan mengenai kepariwisataan perlu ditingkatkan agar semakin banyak masyarakat di sekitar objek wisata Taman Nasional Sebangau Kelurahan Kereng Bangkirai yang sadar akan pentingnya pariwisata dan memiliki kemampuan untuk melihat serta mengelola potensi wisata ekonomi di daerahnya. Pelatihan yang dapat dilakukan antara lain pelatihan tentang pemandu wisata, pelatihan membuat makanan dengan bahan utama kelakai, buah rasau, dan sebagainya. Dan juga pelatihan membuat kerajinan tangan yaitu tikar dari rotan dan purun. Selain itu juga pelatihan tentang tata cara menyambut wisatawan yang berkunjung ke kawasan wisata agar merasa nyaman dan mendapat kesan yang baik.

\section{DAFTAR PUSTAKA}

Borneonews. 2017. Pembangunan sektor pariwisata di Palangka Raya belum maksimal. Diakses dari: https:// www.borneonews.co.id. [15 Januari 2020].

Dewi, M. H. U. 2013. Pengembangan desa wisata berbasis partisipasi masyarakat lokal di Desa Wisata Jatiluwih Tabanan, Bali. Jurnal Kawistara, 3(2), 117-226

Fajriah, S. D., dan Mussadun, M. 2014. Pengembangan Sarana dan Prasarana untuk Mendukung Pariwisata Pantai yang Berkelanjutan (Studi Kasus: Kawasan Pesisir Pantai Wonokerto Kabupaten Pekalongan). Jurnal Pembangunan Wilayah \& Kota, 10(2), 218-233.

llyas, M. 2009. Strategi Pengembangan Pariwisata Kepulauan Togean di Kabupaten Tojo Una-Una.Tesis. Makassar: Program Studi Perencanaan
Pengembangan Wilayah. Program Pascasarjana Universitas Hasanuddin.

Prihanta, W., Syarifuddin, A. and Zainuri, A. M. 2017. Pembentukan Kawasan Ekonomi Melalui Pengembangan Ekowisata Berbasis Masyarakat. Jurnal Dedikasi, 14, 73-84.

Purnamasari, A. M. 2011. Pengembangan masyarakat untuk pariwisata di kampung wisata Toddabojo Provinsi Sulawesi Selatan. Journal of Regional and City Planning, 22(1), 49-64.

Putri, H. P. J., dan Manaf, A. 2013. Faktor-Faktor Keberhasilan Pengembangan Desa Wisata di Dataran Tinggi Dieng. Teknik Perencanaan Wilayah Kota, 2(3), 559-568.

Rahmawati. 2014. Aktivitas Promosi Dalam Menarik Wisatawan Ke Taman Budaya Sendawar Pada Dinas Kebudayaan, Pariwisata, Pemuda Dan Olahraga (Disbudparpora) Kabupaten Kutai Barat. Journal Ilmu Komunikasi, 2(4), 129-139.

Rani, D. P. M. 2014. Pengembangan Potensi Pariwisata Kabupaten Sumenep, Madura, Jawa Timur (Studi Kasus: Pantai Lombang). Jurnal Politik Muda, 3(3), 412 $-421$.

Satria, D. 2009. Strategi Pengembangan Ekowisata Berbasis Ekonomi Lokal dalam Rangka Program Pengentasan Kemiskinan di Wilayah Kabupaten Malang. Journal of Indonesian Applied Economics, 3(1), 37-47.

Soebiyantoro, U. 2010. Pengaruh Ketersediaan Sarana Prasarana, Sarana Transportasi Terhadap Kepuasan Wisatawan. Jurnal Manajemen Pemasaran, 4(1), 16-22.

Sunarjaya, I.G., Antara, M. and Prasiasa, D.P.O. 2018. Kendala Pengembangan Desa Wisata Munggu, Kecamatan Mengwi, Badung. Jurnal Master Pariwisata, 215-227.

Tamelan, P.G. and Harijono, H. 2019. Konsep Ekowisata Sebagai Alternatif Pengembangan Infrasruktur Pariwisata Di Kabupaten Rote Ndao NTT. Jurnal Teknologi, 13(2), 29-35.

Tondobala, L. 2012. Kelayakan pusat Kota Manado sebagai destinasi pariwisata. Media Matrasain, 9(3), 82 $-103$.

Way, I. H., Wuisang, C. E., \& Supardjo, S. 2016. Analisis Kebutuhan Prasarana Dan Sarana Pariwisata di Danau Uter Kecamatan Aitinyo Kabupaten Maybrat Propinsi Papua Barat. Spasial, 3(3), 27-37.

Yudhiantari, L.P.E., 2002. Ekowisata Sebagai Alternatif dalam Pengembangan Pariwisata yang Berkelanjutan di Desa Wongaya Gede, Kecamatan Penebel, Kabupaten Tabanan-Bali [Disertasi]. Semarang: Program Pascasarjana Universitas Diponegoro. 123pp. 